\title{
What Role Can Community-Based Tourism Have in Sustainable Development?
}

\author{
Lina Nasihatun Nafidah*, Lilik Pujiati, Suluh Hendrawan, Nurhayati \\ Department of Accounting \\ STIE PGRI Dewantara \\ Jombang, East Java, Indonesia \\ *lina_nasihatun@stiedewantara.ac.id, lilik_pujiati@stiedewantara.ac.id, suluh.dewantara@gmail.com, \\ nurhayati@stiedewantara.ac.id
}

\begin{abstract}
The 2030 Agenda for Sustainable Development states that its goals are to make sustainable improvements. One of the sustainable improvements is through the independence of the village community. A tourism village is one of the concepts in achieving sustainable developments goals. Community based tourism (CBT) has an impact on local communities in developing countries. This study aims to examine the role of $\mathrm{CBT}$ in reaching these goals. Using a case study approach that focuses on the sustainability of economic, social and cultural life, on protecting the environment, and on maintaining the quality of community life, this research is based on interviews conducted with village leaders, managers of designated Tourist Villages, and the local village communities. The results of this study indicate that the existence of CBT is able to contribute to the sustainability of the economic, social, cultural, and environmental aspects of the community as well contribute to local people's satisfaction with their community life. Thus, CBT plays a role in the achievement of the goals of sustainable development.
\end{abstract}

Keywords—community based tourism, sustainable development

\section{INTRODUCTION}

The existence of village tourism is closely related to sustainable development goals (SDGs). Tourism is considered to be an effective method of reducing poverty [1]. The existence of tourism will help both directly and indirectly to achieve the SDGs. However, on the other hand, tourism can also become an obstacle to achieving these goals if it is not managed properly [2,3]. Village tourism managers must be able to consider the number of opportunities created by adopting the right strategy in achieving the SDGs.

The aims of SDGs include maintaining the sustainability of the social life of the community, maintaining the improvement in the people's economic welfare in a sustainable manner, as well as encouraging inclusive development and improving the quality of people's lives. These aims are also in line with the National Long-Term Development Plan and the National Medium-Term Development Plan. Presidential Regulation Number 59 of 2017 pertaining to the Implementation of Achieving the Sustainable Development Goals.
The concept of Community Based Tourism (CBT) was first introduced by Murphy [4] who showed that the issue of tourism has an impact on local communities in developing countries. CBT has been widely developed in various countries because it has the ability to improve the local economies $[5,6]$. CBT is encouraged as a poverty alleviation strategy and can increase the sustainability of community income which can encourage the achievement of sustainable development goals (SDGs) [7].

The third item on the National Development Agenda in Indonesia is "Developing Indonesia from the periphery by strengthening regions and villages within the framework of the Republic of Indonesia", which is stated in the concept of Nawacita whereby Presidential Regulation Number 2 of 2015 pertaining to RPJMN 2015-2019 is the beginning of changes to the Village government to become an independent Village. This is in line with the goals of sustainable development as stated in Transforming Our World: The 2030 Agenda for Sustainable Development which is referenced by Presidential Regulation Number 59 of 2017 concerning the Implementation of Achieving the Sustainable Development Goals. In line with this, in the program to generate economic growth in villages, the central, provincial and regional governments have a joint commitment to create independent villages by providing a budget for their governments for village development in order to generate economic growth in the village sector; one of these is the Village Fund scheme. Since 2015 the distribution of Village Funds has increased every year with the absorption of the budget also increasing every year in 2015 budget for village funds Rp. $20.6 \mathrm{~T}$ with absorption $82,72 \%$ and in 2019 budget for village funds Rp. $70 \mathrm{~T}$ with village fund absorption $99,54 \%$ (Ditjen PPMD 2020). This shows the extent of potential resources for the village government that can be used to drive an increase in rural economic growth.

Currently, village tourism is an expanding issue. Village tourism, which is a CBT concept, is considered capable of driving village independence, with village tourism increasing the economy and the social and cultural activities of the village community, meaning the participation of the village community will increase. This is in line with the goal of 
achieving SDGs. Therefore, this study aims to analyse the role of CBT in achieving the SDGs.

The development and growth of tourist villages has spread to all provinces in Indonesia, one of which is East Java Province, especially in Jombang regency. The government partipates in the development and management of tourist villages. According to visitor data Central Bureau of Statistics Jombang 2018, the tourist attraction of Jombang Regency in 2018 the number of tourists reached 181,685 visitors. Jombang Regency is an area of beauty with a lot of potential in all parts, such as: nature tourism, craft tourism, and religious tourism. Many of these tourist activities have been developed as an effort to improve the economy of the people of Jombang.

Tourism development aims to provide benefits for tourists and the host community. With the existence of tourism development, it is hoped that it will be able to increase the standard of living of the community through the economic benefits that are brought to the area. In other words, tourism development through the provision of infrastructure facilities, tourists and local residents will benefit from each other. Such development should pay close attention to various aspects, such as cultural, historical and economic aspects of tourist destinations to achieve the goals of sustainable development. The involvement of local communities is the basis for the sustainability of village tourism, it is one of the key elements in tourism development $[8,9]$.

\section{METHODS}

This study used a qualitative field research approach: a case study in a tourist village in Jombang, East Java. This approach aims to understand conditions/practices naturally [10] and to identify sources and informants who can reveal phenomena accurately according to actual conditions [11]. With in-depth semi-structured interviews about the role of the tourism village in achieving the goal of sustainable development. In connection with this, this study uses a sampling technique of a snowball sampling to get in depth-information. We conducted interviews with 15 informants comprising the Village Head, Village Officials, Village Tourism Managers and people from the local Village Community.

The focus of this research is based on the concept of CBT which is about the sustainability of the community's economy, socio-cultural matters, the environment, and quality of life of the community [2]. Apart from focusing on interviews, we also conducted observations at the research location. In order to maintain the anonomity of interviewees, extensive notes were taken during the interview process. Where permitted, we used digital voice recorders. The recorded data were then transcribed and re-read along with detailed handwritten notes taken during the interview. The data analysis technique was carried out using the stages of data collection, data reduction, data presentation and conclusion of the research data.

\section{RESULTS AND DISCUSSION}

Community Based Tourism (CBT) can provide economic and social regeneration while protecting culture against the rising tide of globalization. Economic sustainability comes with the existence of funds for community development, the creation of jobs in the tourism sector, and the emergence of locally-generated income from the tourism sector.

"The existence of this tourism can certainly increase income and help the economy of the community because, on average, local people get jobs in tourism and also the existing tourist facilities are community-owned so the money received from tourists has a positive impact on the local economy". (Village Tourism Manager)

"The tourism will certainly reduce the unemployment rate, with the tourism it can increase employment opportunities [...]". (Village Head)

The social and cultural aims are to encourage people to improve the quality of life, increase community pride and respect for different cultures, foster cross-cultural exchange and ensure that the culture of development is closely attached to local culture.

"[...] the community also participates and supports, [...] in terms of planning, management and decision-making, we cooperate with the community, and to enliven community tourism it also participates by engaging in business and trade to meet the needs of visitors." (Village Head)

"Local people are very enthusiastic about the presence of visitors, but there are still some locals who are rigid and cannot interact with visitors". (Community)

Community participation, namely mutual cooperation in developing a village, is an important cultural value in social life [12]. Community participation is the main asset in realizing the success of Community Based Tourism.

Environmental sustainability is studying the carrying capacity area, regulating waste disposal, increasing awareness of the need for conservation.

"Before the arrival of tourism, the location was a place for household waste disposal for the local community, then the tourism manager developed the tour so as not to damage the environmental ecosystem and keep the environment well preserved, so the manager actually improved and protected the environment. (Tourism Manager)

"The village government also has a mutual cooperation program with the village community to clean up the village [...]". (Village Head)

The quality of life for rural communities is improving. Both the existence of village tourism and the emergence of funds for community economic development can be used to improve facilities and increase in the quality of human resources. Village tourism can help the economy, especially that of local communities. The majority of people's income is obtained from tourism-related sources in the village such as selling things at 
tourist attractions. And tourism can create jobs in the tourism sector for the surrounding community.

Thus, the existence of village tourism is closely related to the SDGs. CBT encourages sustainable tourism on the economic side of rural communities, socio-cultural sustainability, preservation of the environment, and the quality of community life [2] which leads to the achievement of SDGs. CBT can directly eradicate poverty and hunger, as well as generate capital and innovation to develop a better quality community. CBT can contribute to the socio-economic sustainability of development goals, namely SDGs [7].

\section{CONCLUSION}

The empirical findings show that $\mathrm{CBT}$ has a role in achieving the SDGs. CBT is proven to be able to stimulate the village economy. This is reflected in the increase in the economy of the village community, and the existence of job opportunities for members of the community. In addition, the quality of life of the community also heads in a better direction. With CBT, the potential of the village can be explored properly so that the condition of the village environment is getting better in a way which is still in harmony with the social and cultural values of the village community.

This study contributes to the literature on CBT development which has been proven to make a contribution to the achievement of the SDGs. Thus, it is expected that further research would conduct generalized empirical tests related to the development of CBT in terms of the achievement of the SDGs. Therefore, it will be able to provide encouragement for government policies to develop tourism in villages using the concept of CBT, so that the tourism being developed still considers important factors, namely the environment, sociocultural matters, and the sustainability of the community's economy and quality of life. The role of the community in developing village tourism, especially in terms of socioeconomic empowerment, is also necessary so that communitybased tourism is used as a kind of new paradigm of tourism development that carries the principles of sustainable development. In this way, village development through village tourism with the CBT concept can still pay attention to local values.

\section{REFERENCES}

[1] R. Croes, "The Role of Tourism in Poverty Reduction: An Empirical Assessment," Tourism Economics, vol. 20, no. 2, pp. 207-226, Apr. 2014.

[2] T.H. Lee and F.H. Jan, "Can community-based tourism contribute to sustainable development? Evidence from residents' perceptions of the sustainability," Tourism Management, vol. 70, no. September 2018, pp. 368-380, 2019.

[3] L.N. Nafidah, N. Soewarno, and B. Tjahjadi, "Challenges for Implementation of Village Innovation Policy in Realising Sustainable Development," International Journal of Innovation, Creativity and Change, vol. 13, no. 7, pp. 634-646, 2020.

[4] P.E. Murphy, "Tourism: A Community Approach (RLE Tourism) - 1st Edition," CRC Press: Boca Raton, FL, USA, 1985. [Online]. Retrieved from: https://www.routledge.com/Tourism-A-Community-ApproachRLE-Tourism/Murphy/p/book/9780415751490 [Accessed on: 06-Nov2020].

[5] T.H. Lee, F.H. Jan, and C.C. Yang, "Conceptualizing and measuring environmentally responsible behaviors from the perspective of community-based tourists," Tourism Management, vol. 36, pp. 454-468, 2013.

[6] R. Dodds, A. Ali, and K. Galaski, "Mobilizing knowledge: determining key elements for success and pitfalls in developing community-based tourism," Current Issues in Tourism, vol. 21, no. 13, pp. 1547-1568, Sep. 2018.

[7] L.O. Juma and A. Khademi-Vidra, "Community-based tourism and sustainable development of rural regions in Kenya; Perceptions of the citizenry," Sustainability (Switzerland), vol. 11, no. 17, 2019.

[8] H. Sakata and B. Prideaux, "Community-based ecotourism: opportunities and difficulties for local communities and link to conservation - ResearchOnline@JCU," 2014. [Online]. Retrieved from: https://researchonline.jcu.edu.au/37757/ [Accessed on: 08-Nov-2020].

[9] M. Muganda, A. Sirima, and P.M. Ezra, "The Role of Loca Communities in Tourism Development: Grassroots Perspectives from Tanzania," Journal of Human Ecology, vol. 41, no. 1, pp. 53-66, Jan. 2013.

[10] L.D. Parker and D. Northcott, "Qualitative Generalising in Accounting Research: Concepts and Strategies," Accounting, Auditing \& Accountability Journal, vol. 29, no. 6, pp. 1100-1131, 2016.

[11] S. Kinnear and I. Ogden, "Planning the Innovation Agenda for Sustainable Development in Resource Regions: A Central Queensland Case Study," Resources Policy, vol. 39, no. 1, pp. 42-53, 2014.

[12] L.N. Nafidah, B. Thahjadi, and N. Soewarno, "The Pseudo-Culture Financial Management Risk In Village Government," Opcion, vol. 36, no. 26, pp. 2759-2791, 2020. 